\title{
Perspective
}

PERSPECTIVE Actualité en histoire de l'art

Comptes rendus | 2007

\section{Jacques Lacoste, Les grandes œuvres de la sculpture romane en Béarn, Sud-Ouest, Bordeaux, 2007}

\section{Thomas Creissen}

\section{OpenEdition}

\section{Journals}

Édition électronique

URL : http://journals.openedition.org/perspective/2993

DOI : $10.4000 /$ perspective. 2993

ISSN : 2269-7721

Éditeur

Institut national d'histoire de l'art

Référence électronique

Thomas Creissen, « Jacques Lacoste, Les grandes œuvres de la sculpture romane en Béarn, Sud-Ouest, Bordeaux, 2007 », Perspective [En ligne], Comptes rendus, mis en ligne le 09 août 2013, consulté le 01 octobre 2020. URL : http://journals.openedition.org/perspective/2993 ; DOI : https://doi.org/10.4000/ perspective.2993

Ce document a été généré automatiquement le 1 octobre 2020. 


\section{Jacques Lacoste, Les grandes œuvres de la sculpture romane en Béarn, Sud- Ouest, Bordeaux, 2007}

Thomas Creissen

\section{RÉFÉRENCE}

Jacques Lacoste, Les grandes ceuvres de la sculpture romane en Béarn, Sud-Ouest, Bordeaux, 2007. 
L'ouvrage de Jacques Lacoste prolonge des hypothèses qu'il avait déjà formulées, notamment dans La sculpture romane en Béarn : " le Grand Atelier » (Bizanos, 1996) et dans Les maîtres de la sculpture romane dans l'Espagne du pèlerinage à Compostelle (Luçon, 2006). Il s'efforce, pour l'essentiel, d'étudier l'émergence de la sculpture en Béarn en retraçant le parcours d'un certain nombre de sculpteurs dont la personnalité artistique est soi-disant bien définie - le Maître de Morlaas, le Maître de Sainte-Marie d'Oloron... - ou bien de leurs «compagnons». Les œuvres sculptées sont replacées dans leur contexte architectural, et l'auteur aborde à plusieurs reprises la question des programmes et celle de la personnalité des commanditaires. Toutefois, l'ouvrage s'intéresse avant tout à la circulation des

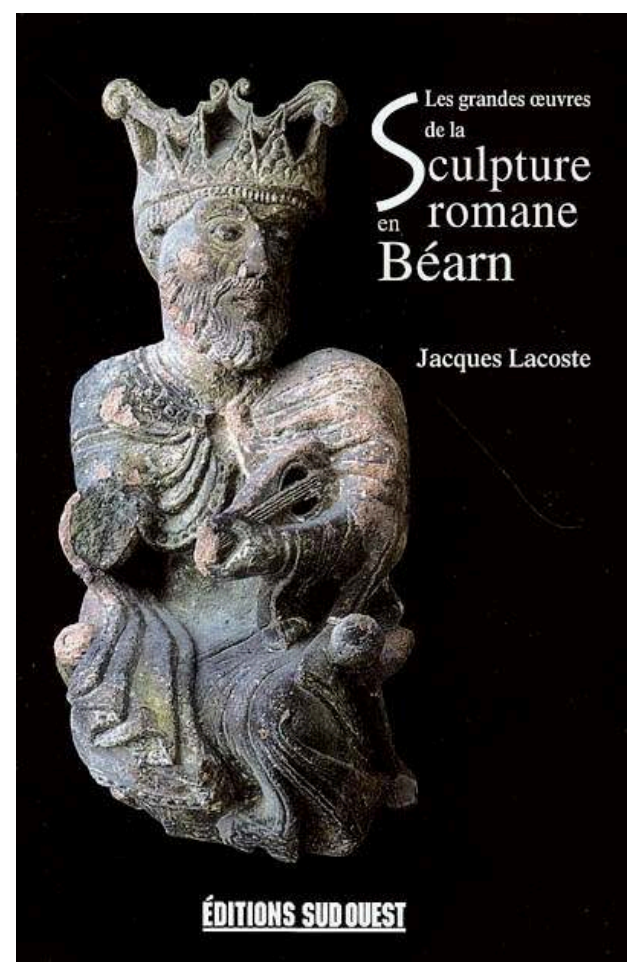
formes restituée à partir de comparaisons à vrai dire pas toujours convaincantes.

\section{AUTEURS}

\section{THOMAS CREISSEN}

31 décembre 2010 